\title{
MEDICAL AND PROCEDURAL-LEGAL ASPECTS OF INPATIENT AND OUTPATIENT FORENSIC PSYCHIATRIC EXAMINATION
}

DOI: 10.36740/WLek202007141

\author{
Sandra Kaija' ${ }^{1}$ Inga Kudeikina' ${ }^{1}$, Nataliya Gutorova ${ }^{2}$ \\ 'RIGA STRADINS UNIVERSITY, RIGA, LATVIA \\ 2ACADEMICIAN STASHIS SCIENTIFIC RESEARCH INSTITUTE FOR THE STUDY OF CRIME PROBLEMS, KHARKIV, UKRAINE
}

\begin{abstract}
The aim: The aim of the study is to define the legal framework of forensic psychiatric examination commissioned by the court in relation to the competence of medical practitioners and the position of the subject as a patient in the process of forensic psychiatric examination in order to determine the correlation of special legal regulation with criminal and civil procedure regulation and to make proposals for the enhancement of the legal regulation.

Materials and methods: This study is based on the analysis of international law, medical civil procedure and criminal procedure legislation, juridical practice, medical law legal doctrine. The following methods were used in this research: the method of interpretation of legal norms, analysis of legal acts, and the induction-deduction method, upon which the conclusions were drawn and recommendations were provided.

Conclusion: The current regulatory framework does not provide for the procedure by which the subject's medical treatment is conducted during forensic psychiatric examination, nor does it determine the criteria for the admissibility of treatment of the persons concerned and the extent of treatment. During the examination, the medical practitioner who is in the expert's procedural position in relation to the subject under examination in the particular examination should not carry out the treatment of the subject.
\end{abstract}

KEY WORDS: accountability, legal capacity, criminal proceedings, civil proceedings, medical treatment, expert

Wiad Lek. 2020;73(7):1533-1538

\section{INTRODUCTION}

The legal scope of treatment should not be narrowly understood in its generally understood sense of a set of actions aiming to restore human health or prevent disease. Criminal and civil proceedings involve procedural means other than treatment as "professional prevention, diagnosis and treatment of a specific disease, medical rehabilitation and patient care" $[1 ; 2]$, which are carried out by medical practitioners in criminal and civil proceedings based on the basis of the decision of the person directing the proceedings. It is a forensic psychiatric expert-examination commissioned by the court. Today's mental health experts working in the criminal justice field have an increasing burden of responsibility as a result of their wider role, and potentially greater power to harm [3].

When making the proper forensic qualification of the case and making a lawful and just decision in the case, the forensic psychiatric examination plays an important and sometimes decisive role.

Forensic psychiatric assessment regarding liability ensures the balance between justice and psychiatry [4]. Such an examination is necessary in many cases, but its conduct should not lead to a violation of fundamental human rights and freedoms.

Criminal liability applies to a person, who is an essential principle of criminal procedure, while in civil law, actions conducted by the person in the state of mental incapacity may be invalidated, thereby terminating the existing legal relationship or preventing its establishment.

\section{THE AIM}

The aim of this research is to define the legal framework of forensic psychiatric examination in relation to the competence of medical practitioners and the position of the subject as a patient in the process of forensic psychiatric examination in order to establish the correlation of special legal regulation with criminal and civil procedural regulation and make proposals for enhancing the regulatory framework.

\section{MATERIALS AND METHODS}

This study is based on the analysis of international law, medical civil procedure and criminal procedure legislation of the Republic of Latvia and Ukraine, the authors' own experience in legal practice, medical law legal doctrine. Totally 14 laws and papers were analyzed. There were used the methods of interpretation of legal norms, analysis of legal acts, and the induction-deduction method, which were followed by conclusions and recommendations.

\section{REVIEW AND DISCUSSION}

The issue of the ability of the natural person, the legal entity, to understand the motives of his or her actions or omissions, to conduct his actions consciously, and to be aware of the consequences of such actions or omissions 
is central to deciding on a person's legal liability or the validity of the civil transaction entered into by the person. This total set of such elements is referred to as the institute of legal capacity.

There is a distinction between medical and legal aspects of the legal capacity. The former aspect is inextricably linked to a person's cognitive abilities and derives from a person's mental health. It is logical that the assessment of a person's abilities can only be performed by a person with specialist knowledge - a medical practitioner or a person who has medical education and provides medical treatment $[1 ; 2]$. On the other hand, the latter, legal, aspect is related to the objectively determined state of health of the person under investigation and the subjective attitude of this person, which is expressed in the understanding of one's actions or omissions and their consequences. Thus, this is how the state of mental health affects a person's ability to act, which in legal science is interpreted as the ability to understand and take responsibility for one's actions [5]. In summary, the person with legal capacity is a person able to act. However, not always do the medical and legal aspects coincide - a person may not be mentally ill and yet, for a specific offense or transaction, this person may be considered legally incapable or incapacitated, or vice versa - a mentally ill person may be recognized as legally capable. Thus, medical and legal sciences fuse in one process. A judicial officer (the person directing the proceedings the court or judge), based on the opinion of the medical practitioner, assesses the person's legal capacity.

The issue of declaring a person incapable of committing an offense or of entering into a civil transaction cannot be left to the sole discretion of this individual or the person directing the proceedings. The individual is always interested in the outcome of the case and therefore cannot be impartial, yet, neither he/she nor the person directing the proceedings have specialist medical knowledge, the need for which has already been mentioned. It serves as a legal instrument for the forensic psychiatric examination, which seeks to answer the question of whether the person is considered to have legal capacity for the incriminated criminal offense (criminal law) or for entered transaction, when having legal capacity (civil law).

Expert-examination is a total set of procedural acts, therefore, its procedure is determined by the Latvian and Ukrainian procedural laws - Criminal Procedure Law of the Republic of Latvia [6], Criminal Procedure Code of Ukraine [7], Civil Procedure Law of the Republic of Latvia [8], Civil Procedure Code of Ukraine [9]. Considering the fact that the subject of forensic psychiatric examination is a human being, that is, a living being and this examination pertains to human health, it cannot be denied that the scope of medical expertise includes the application of the Medical Treatment Law of the Republic of Latvia [1], Fundamentals of Ukrainian legislation on healthcare [2], etc., and the legal acts that regulate medical treatment.

In addition, as a total set of medical-procedural activities, this examination creates a collision between the involved persons. The examiner is both a medical practitioner and an expert (i.e., an official with special statutory rights and obligations). The performer of the expertise is both a medical practitioner and an expert (i.e., an official with the rights and obligations under the specific law).

The person who is subject to the examination has a certain procedural status applicable to him or her in the case, but this does not exclude the extension of this status to the patient's rights. Special attention shall be paid to these issues in the case of inpatient forensic psychiatric examination commissioned by court (hereinafter - examination), when the person's freedom, which is one of the basic human rights, is restricted [10].

According to the scientific literature, in the case of examination, deprivation of liberty formally begins when the fact of conducting examination in criminal proceedings, since it is possible to carry it out under compulsion [11]. In criminal proceedings, a person with the procedural status of a suspect or accused person is a priori subject to certain limitations because of his or her status. The situation is different in civil proceedings, in which persons are not subject to state coercive measures because the process is between individuals, and yet, examination is still admissible. Part I of Section 121 of the Civil Procedure Law of the Republic of Latvia provides that the examination is to be determined at the request of a party in cases where special scientific knowledge is required to clarify the relevant facts of the case [8]. The same rules are provided for by Articles 103-105 of the Civil Procedure Code of Ukraine [9] Thus, in civil proceedings, the significance of the facts to be ascertained for the proper resolution of the case is the legitimate basis for conducting the examination. This involves the duty of the court to ascertain the objective truth, as required by Section I of Article 17 of the law "On the Power of the Court" [12]. Consequently, only the facts which are relevant to the proper settlement of the case may be the subject of a request for examination. The facts to be recognized as significant, first and foremost, pertain to the the person's legal capacity. The incapacity of a person destroys the force of a transaction, so the transaction entered into by the incapacitated person is void. This follows from Paragraph 1405 of the Civil Code of the Republic of Latvia [13]. On the other hand, when assessing a person's legal capacity, it is necessary to prove the connection between the person's actual capacity and the restriction of legal capacity [14]. This entails the necessity to prove that at the time of the conclusion of the transaction, the actual ability of the person to be aware of and manage his or her activities match the medical criteria of legal capacity.

In turn, in criminal cases, in accordance with Section I of Paragraph 596 one of the Criminal Procedure Law of the Republic of Latvia [6] and Section 1 of Article 509 of the Criminal Procedure Code of Ukraine [7], the person directing the proceedings shall determine a court psychiatric examination for a suspect or accused, if information has been acquired in criminal proceedings regarding the fact that a person ill with mental disturbances committed a criminal offence while in a state of mental incapacity, or has fallen ill following the committing of the criminal offence. 
Mens rea is the mental element of an offense, and psychiatric disorders have the potential to influence the competency or capacity to form any particular intention or behaviour that can lead to a crime. Therefore, psychiatrists are frequently asked to evaluate a defendant's mental state at the time of the offense to determine the required mens rea that is related to the crime. [15]

Legal professionals such as judges can provide a legal assessment of the situation, but cannot assess the medical criteria for a person's legal capacity. The medical criteria are evaluated by experts, specifically, by medical practitioners during the examination.

The forensic experts who are independent and law-abiding officials have the right to conduct such examinations. There are two types of forensic experts in Latvia - public forensic experts and private forensic experts [16]. It should be emphasized that private forensic experts do not have the right to conduct inpatient forensic psychiatric examination, but have the right to carry out outpatient forensic psychiatric examination. In contradistinction to Latvia, according to Ukrainian legislation, the forensic psychiatric examination is carried out only by state expert institutions [17].

In the Republic of Latvia, the Cabinet determines the procedure by which forensic psychiatric examinations shall be performed. Furthermore, it can be concluded that both outpatient and inpatient forensic psychiatric examinations are conducted at forensic institutions, psychiatric treatment institutions or outpatient psychiatric facilities [18]. Similar provisions are also contained in the by-law of Ukraine - the Procedure for conducting forensic psychiatric examination established by the Ministry of Health [19]. It is evident that the examination can be carried out not only in an institution which is institutionally separated, for example, a specialized forensic institution can be recognized as such type of institution, but also in a general psychiatric institution or its outpatient facility. It should be highlighted that the above mentioned Latvian Cabinet of Ministers Regulations [18] have been issued in accordance with Section 72 of the Medical Treatment Law [1], as well as Ukrainian Minister of Health Order [19] have been issued in accordance with Article 71 of the Fundamentals of Ukrainian Legislation on Healthcare [2]. It emphasizes the close connection of forensic psychiatric examination with the treatment and consecutively with the patient's rights. Any person who, by voluntary or involuntary admission to a medical institution due to medical manipulation, enjoys the patient's rights, the extent of which may vary depending on the procedural status of the person concerned. This is an expression of the dual nature of a person's legal state, which correlates the patient's rights with the legal status established in criminal or civil proceedings.

Certainly, the rights of the patient are not absolute, but the fact that a person has been granted a certain procedural status in the case does not in itself justify depriving the person of the patient's rights. To what extent can a patient's rights be restricted if a person is admitted to a medical institution for examination?

When performing forensic psychiatric examination, the person is admitted to a general medical institution and the patient's rights are applied to him or her. While at a medical institution, the person concerned is a patient. There are no exceptions in the Patient's Rights Law consistently with which it can be argued that this law does not apply to persons admitted to a medical institution for psychiatric examination. A doctor - expert is primarily a medical practitioner who simultaneously provides treatment for patients and works as an expert medical practitioner at the same medical institution.

Forensic psychiatric examination is always based on a reasonable doubt about the person's mental state. Therefore, because of age or illness, a person's cognitive abilities are in doubt. In such cases, the person has often been previously treated for mental illness. Psychiatric care is based on a voluntary basis $[1 ; 2]$. This is the way in which patients' rights are respected, specifically, according to Paragraph I of Article 6 of the Patient's Rights Law, medical treatment can be conducted only with the informed consent of the patient [20]. It is only in exceptional cases that psychiatric treatment without the consent of the person and forced placement in a psychiatric institution is permissible. These exceptions are specified in Section 68 of the Medical Treatment Law, namely, (1) the person concerned has threatened or threatens, tried or is trying to do personal injuries to him or herself or to another person or has behaved or behaves violently to other persons and a medical practitioner has determined that the patient has a mental health disorder for which the possible consequences may be personal injury to the patient him or herself or another person; 2) the patient has indicated or indicates an inability to care for him or herself or for a person under his or her guardianship and a medical practitioner has determined that the patient has a mental health disorder for which the possible consequences may be unavoidable and serious deterioration of the person's health.

Evidently, the placement of a person in a psychiatric medical institution for inpatient forensic psychiatric examination is not regulated by the Latvian Medical Treatment Law [1] as well as Fundamentals of Ukrainian legislation on healthcare [2], which is considered to be a deficiency of legal regulation, because in matters related to person's health, to matters pertaining to the person as a living creature being admitted to a medical institution, there is a need for the application of a special law, not the procedural law regulating the procedure for carrying out procedural acts. However, the legal framework requires the examined person to give a written consent for conducting examination $[18 ; 19]$. At the same time, it should be emphasized that there are no legal consequences and no further action to be carried out by the person directing the proceedings if the examined person refuses to give his or her consent. The legislator has included contradictory requirements in the legal framework, which do not help to eliminate doubts, specifically, if the examined person is or is not endowed with the patient's rights and in which cases the forensic psychiatric examination may be carried out under compulsion.

Inpatient forensic psychiatric examination is associated with a greater restriction of personal freedom than inpa- 
tient examination. Therefore, inpatient forensic psychiatric examination can only be performed if the research necessary for handling matters significant for the case can be carried out in an inpatient setting $[18 ; 19]$. And yet, deciding on the type of examination - outpatient or inpatient - is the responsibility of the forensic expert himself/ herself. The expert's decision to conduct inpatient forensic psychiatric examination is not subject to judicial review the legislator has not provided for appeals.

It should be emphasized that there is no provision for inpatient forensic psychiatric examination in civil proceedings. According to Paragraph II of Article 267 of the Civil Procedure Law of the Republic of Latvia [8] as well as According to Paragraph 3 of Article 103 of the Civil Procedure Law of Ukraine [9], if the person subject to the proceedings avoids expert-examination, engaging the public prosecutor, the court may order that the person be subjected to forensic psychiatric examination under compulsion. It must be concluded that it is not possible for the person concerned to deny such examination. The refusal relates only to the refusal to arrive for examination voluntarily, but if refused, he or she will be subject to coercive measures and will be forcibly admitted for the outpatient forensic psychiatric examination. The participation of the prosecutor in the decision-making process ensures the observation of the rule of law, because forced examination restricts the freedom of the person.

Article 283 of the Criminal Procedure Law of the Republic of Latvia [6] provides for the possibility of a suspect, accused, or the person in relation to whom proceedings have been initiated for the determination of compulsory measures of a medical nature may be forcibly placed in a medical institution for the performance of an expert-examination, if the research necessary in a forensic or court psychiatric examination for the solving of matters significant to the case can be carried out only under medical inpatient conditions. A person may be placed in a medical institution for the performance of an expert-examination, on the basis of a decision of the investigating judge or court decision, only if the decision has also been taken on determination of the relevant expert-examination. The decision to be placed in a medical institution for examination is subject to appeal in court.

Under Paragraph I, Clause 5 of Paragraph II of Section 26 of the Criminal Procedure Law of the Republic of Latvia, forensic psychiatric examiners of the court have the power to conduct criminal proceedings on behalf of the State. Paragraph I and Clause I of Paragraph II of Section 33 of the Criminal Procedure Law of the Republic of Latvia provide that the expert of the examination body has the power to conduct criminal proceedings, as well as the expert on behalf of the person directing the proceedings conducts examination if it is necessary to carry out research using specialist knowledge, devices and substances to obtain the information necessary to prove the case. Paragraph 4 of Article 61, Clause 4 of Paragraph I of Article 67 of the Criminal Procedure provide that the person against whom the criminal proceedings have been initiated shall be required to authorize his/her expert-examination and to issue samples for comparative investigation which are independent of the person's will. Similar provisions are also contained in Article 509 of the Criminal Procedure Code of Ukraine [7].

In view of the foregoing, the examined persons that are subject to criminal proceedings may, in the context of inpatient forensic psychiatric examination, be subject to restrictive measures and non-disclosure if this is necessary for conducting the proceedings and does not conflict with the rights of the persons against whom criminal proceedings have been initiated, but shall not be permitted where this is not justified by the procedural steps. It should be emphasized that forensic psychiatric experts have an obligation and an opportunity to become acquainted with the materials of the criminal proceedings, which may affect the quality of treatment.

Forensic psychiatric examination is a widely applicable means of proof in civil proceedings. The Civil Procedure Law of the Republic of Latvia [8] provides for the performance of examination in cases involving the restriction of a person's legal capacity (Chapter 33 of the Civil Procedure Law). And yet, the categories of such cases are not the only ones when it is essential to ascertain the person's legal capacity. As mentioned above, there is a need for such categories in cases where an action is called to be recognized as void on the ground that the person that has committed it at the time of the transaction or commitment of this action had legal incapacity. Analyzing the norms of the Civil Procedure Law of the Republic of Latvia [8], it has to be concluded that there is no general procedure for determining and conducting forensic psychiatric examination. The issues regarding the limitation of a person's legal capacity are subject to special court procedure, but the procedure of forensic psychiatric examination within the procedure of claims is not specified. In most cases, the claim procedure in litigation are cases of invalidation of the transaction on the ground that the person was legally incapable at the time of the conclusion of the transaction, and in such cases it is the expert's opinion that is crucial for the establishment of the truth. The person's mental state is assessed solely on the basis of other evidence provided in civil proceedings (statements of the parties, witness testimony, written evidence) and without forensic psychiatric examination, i.e. without the involvement of a person with medical expertise, such evidence and assessment are considered incomplete.

As Professor V.Bukovskis has pointed out, the expert is considered to be an objective assistant to the judge in matters where the court lacks knowledge [21]. This demonstrates the need for expertise in much broader issues. It is, however, the prerogative of the parties to request the expert-examination. This fact has also been pointed out by the Supreme Court of the Republic of Latvia, which noted that it is not possible to oblige the parties to take procedural steps, in this case, to request the expert-examination [22].

The essence of forensic psychiatric examination is to ascertain the facts relevant to the case if they require 
specialized knowledge which the person who directs the proceedings does not possess. What is to be recognized as an essential fact is not specified in the legal framework, it must be decided on a case-by-case basis. Forensic psychiatric examinations are performed in outpatient settings but also in inpatient medical facilities, when the fact ascertion is impossible in the outpatient settings. Both types of examination are to be performed in the examination institution and a general medical institution. Within the framework of procedural regulation, forensic psychiatric examination is not identifiable with medical treatment. However, given that some components of forensic psychiatric examination have been linked to treatment by the legislature (the consent of the subject, the location of examination in a medical facility), it cannot be denied that the process of forensic psychiatric examination includes treatment elements. Forensic psychiatrists have a dual status. Namely, they are medical practitioners and are subject to the rules of law deriving from the Medical Treatment Law, and at the same time, they have a special procedural status - an expert who is subject to the rules of criminal and civil law. Different legal frameworks create different legal consequences and, in some cases, hierarchical problems. Similar issues are with the status of the subject of such examination. There is no restriction of personal liberty in civil proceedings, which is why there is no reason to ascert that the person subject to the examination in civil proceedings is not endowed with the rights of a patient; however, in some cases there is applied a coercive mechanism, namely, forced transfer of a person to an expert-examination. Such forced transportation must not be confused with forcing expert-examination. In civil proceedings, unlike in criminal proceedings, there is no provision for placing a person in a psychiatric medical institution for compulsory examination. In private law, forcing a person into a psychiatric treatment facility would be an excessive restriction of a person's freedom, given that examination in civil proceedings is conducted only at the request of one of the parties, which presupposes voluntary cooperation. At the same time, however, there are downsides to this, as non-cooperation by the person concerned may prevent the truth of the case from being established.

The scope of the patient's rights ends when the implementation of the coercive measures provided for in the criminal proceedings is carried out, which may be applied to the person concerned in order to carry out the procedural act - the expert-examination. Restrictions that do not pertain to forensic psychiatric examination are not permissible.

\section{CONCLUSIONS}

Forensic psychiatric examination has several levels of coverage. The expert is an official duly approved by law and is also a doctor. Similarly, the examined person is the person whose duties and rights are determined by the procedural law and is also a patient with a much broader range of rights. These statuses interact. During the forensic psychiatric examination, the medical practitioner does not perform medical treatment consistently with the Medical Treatment Law of the Republic of Latvia [1]. According to Ukrainian legislation [19], during a stationary forensic psychiatric examination, if there are indications, medications can be used only with the informed consent of the person and under the standards of treatment. However, such use of drugs cannot be considered a full-fledged treatment.

Forensic psychiatric examination is limited at a specific time when the subject under investigation is evaluated using a scientific and legal methodology. The examiner is limited by the task assigned by the person directing the proceedings, namely, the questions posed in the decision ordering the examination, to which the forensic expert must provide answers.

The current regulatory framework does not provide for the procedure by which the subject's medical treatment is conducted during forensic psychiatric examination, nor does it determine the criteria for the admissibility of treatment of the person concerned and the extent of such treatment.

During the examination, which is a long and continued process, the medical practitioner, who, within the specific examination framework, has the expert's procedural status in relation to the subject of the examination, should not carry out treatment of this person. However, in the case of forensic psychiatric examination, it cannot be denied that the subject of investigation may be treated. This treatment is carried out by the same person who conducts expert-examination. In this case, different procedural states of the same person, such as the status of the medical practitioner (doctor) and expert, are merged.

Given that forensic psychiatric examiners must first and foremost have the appropriate qualifications to qualify to carry out expert-examinations, it is understandable that there should in fact be a sign of equivalence between the doctor and the expert, but given that the medical practitioner and the expert have different competencies, it shall not be allowable for the same person to conduct both the treatment and expert-examination of one person in the context of one process.

Within the legal framework, it is necessary to distinguish between the regulation of the examination process and the treatment, while conducting examination. In the first instance, it should be stipulated that forensic psychiatric examination is to be carried out only in a specialized forensic institution where the examination is carried out by an expert who does not provide treatment in any other medical institution. This would help to distinguish the procedural rights of the expert and the doctor and would clearly draw the line between treatment and examination. Secondly, the legal framework must determine the patient's rights as the subject of the examination, since, even in the case of an examination, there shall be no interference with the person's integrity against his or her will.

Subjection to forced forensic psychiatric examination should only be allowed in cases analogous to the provision of psychiatric help without the patient's consent. There should be a clear legal framework in criminal proceedings that is 
in line with human rights and guarantees the protection of a person's fundamental rights when placed in a psychiatric institution. This aspect is particularly important because the decision to conduct inpatient forensic psychiatric examination is made by an expert and is not subject to appeal.

Failure of the subject of examination to cooperate with the expert and refusal of inpatient forensic psychiatric examination would be likely to interfere with the clarification of the truth, but is proportionate to the individual's fundamental rights. It should not be forgotten that the expert opinion has no predetermined probative value, as it is evaluated in conjunction with other evidence so that the court does not have only one piece of evidence.

Forced placement for expert-examination in a psychiatric treatment facility is not allowed in civil proceedings. However, the person who is subject to criminal proceedings in the context of inpatient forensic psychiatric examination is permitted to be exposed to the application of restrictive measures and the non-disclosure of information if this is necessary for conducting the proceedings and does not conflict with the rights of the person against whom criminal proceedings have been initiated, and yet it is not allowable unless procedural steps justify it.

\section{REFERENCES}

1. Medical Treatment Law: Law of the Republic of Latvia. Entry into force 01.10.1997. Published in: Latvijas Vēstnesis, 167/168, 01.07.1997.; https://likumi.lv/ta/en/en/id/44108-medical-treatment-law.

2. Fundamentals of Ukrainian Legislation on Healthcare. Entry into force 15.12.1992. URL: https://zakon.rada.gov.ua/laws/show/2801-12

3. Paul E. Mullen. The psychiatric expert witness in the criminal justice system. Criminal Behaviour and Mental Health. 2010. Volume 20, Issue 3. https://doi.org/10.1002/cbm.764.

4. Guivarch J., Piercecchi-Marti MD., Glezer D., Chabannes JM. Differences in psychiatric expertise of responsibility: Assessment and initial hypotheses through a review of literature. Encephale. 2015; 41(3); doi: 10.1016/j. encep.2015.03.002.

5. Rīcībspēja. Akadēmiskā terminu datu bāze AkadTerm. Pieejams: http:// termini.lza.lv/term.php?term=rīcībspēja\&list=rīcībspēja\&lang $=\mathrm{LV}$

6. Criminal Procedure Law: Law of the Republic of Latvia. Entry into force 01.10.2005. Published in: Latvijas Vēstnesis, 74, 11.05.2005.; https:// likumi.lv/ta/en/en/id/107820-criminal-procedure-law

7. Criminal Procedure Code of Ukraine. Entry into force 19.11.2012. URL: https://zakon.rada.gov.ua/laws/show/4651-17

8. Civil Procedure Law: Law of the Republic of Latvia. Entry into force 01.03.1999. Published in: 03.11.1998. "Latvijas Vēstnesis" Nr.326/330. https://likumi.Iv/ta/en/en/id/50500-civil-procedure-law

9. Civil Procedure Code of Ukraine. Entry into force 01.09.2005. URL: https://zakon.rada.gov.ua/laws/show/1618-15

10. Convention for the Protection of Human Rights and Fundamental Freedoms. International documents. Rome, 4.XI.1950. URL: https:// www.echr.coe.int/Documents/Convention_ENG.pdf

11. Fenwick, H. Civil Liberties and Human Rights., Abingdon, Oxon: Routledge-Cavendish, 2007.

12. On Judicial Power: Law of the Republic of Latvia. Entry into force 01.01.1993. Published in: Latvijas Republikas Augstākās Padomes un Valdības Ziṇotājs, 1/2, 14.01.1993. https://likumi.lv/ta/en/en/ id/62847-on-judicial-power
13. The Civil Law. Part four. Obligations Law: Law of the Republic of Latvia. Entry into force 01.03.1993. Valdības Vēstnesis, 46, 26.02.1937. https:// likumi.lv/ta/id/90220-civillikums-ceturta-dala-saistibu-tiesibas

14. Latvijas Republikas Augstākās tiesas spriedums lietā SKC-[I]/2017. Pieejams: http://www.at.gov.Iv/lv/judikatura/judikaturas-nolemumuarhivs/civillietu-departaments/klasifikators-pec-lietu-kategorijam/ civilprocesa-likums/b-dala-tiesvediba-pirmas-instances-tiesa-127-40610pants/sesta-sadala-seviska-tiesasanas-kartiba-251-3945-pants/33nodalapersonas-ricibspejas-ierobezosana-un-aizgadnibas-nodibinasana-garigarakstura-traucejumu-del-264-270pants (aplūkots 23.11.2019.)

15. Solmaz, Mustafa. Forensic psychiatric expert witnessing in criminal and civil law. Psychiatry and Clinical Psychopharmacology, 2019, V0L. 29, N0. S1, 330 https://doi.org/10.1080/24750573.2019.1606883.https:// www.tandfonline.com/doi/pdf/10.1080/24750573.2019.1606883

16. Law On Forensic Experts: Law of the Republic of Latvia. Entry into force 15.03.2016. Latvijas Vēstnesis, 42, 01.03.2016. https://ikumi.lv/ta/ en/en/id/280576-law-on-forensic-experts

17. About Forensic: Law ofUkraine. Entry into force 21.04.1994. URL: https:// zakon.rada.gov.ua/laws/show/4038-12

18. Tiespsihiatriskās ekspertīzes veikšanas kārtība. 13.11.2018. Ministru kabineta noteikumi Nr.695. Publicēts: Latvijas Vēstnesis, 226, 15.11.2018.

19. Pro zatverdzhennia poriadku provedennia sudovo-psykhiatrichnoi ekspertyzy. Nakaz Ministerstva okhorony zdorovia Ukrainy vid 08.05.2018 № 865 [About the Procedure for conducting forensic psychiatric examination. Order of the Ministry of Health of Ukraine, 08.05.2018 № 865]. URL: https://zakon.rada.gov.ua/laws/show/z0719-18

20. Law 0n the Rights of Patients: Law of the Republic of Latvia. Entry into force 01.03.2010. Latvijas Vēstnesis, 205, 30.12.2009. https://likumi. Iv/ta/en/en/id/203008-law-on-the-rights-of-patients

21. Bukovskis, V. Civilprocesa mācību grāmata. Rīga, Autora izdevums: 1933., 388.Ipp.

22. Latvijas Republikas Augstākās tiesas 2014.gada 30.maija spriedums lietā SKC-88/2014. Nepublicēts materiāls.

\section{ORCID and contributionship:}

Sandra Kaija: 0000-0002-2711-613X ${ }^{A, D, F}$

Inga Kudeikina: 0000-0002-7895-4264 ${ }^{B, D, F}$

Nataliya Gutorova: 0000-0003-2485-0651 ${ }^{B, E, F}$

\section{Conflict of interest:}

The Authors declare no conflict of interest.

\section{CORRESPONDING AUTHOR Nataliya Gutorova}

Academician Stashis Scientific Research Institute for the Study of Crime Problems, Kharkiv, Ukraine e-mail: natalygutorova@gmail.com

Received: 11.04 .2019

Accepted: 22.06 .2020

A - Work concept and design, B - Data collection and analysis, C - Responsibility for statistical analysis, D-Writing the article, $\mathbf{E}$-Critical review, $\mathbf{F}$ - Final approval of the article 